\title{
Evidence that the biocontrol agent Bacillus cereus synthesizes protein that can elicit increased resistance of tomato leaves to Corynespora cassiicola
}

\author{
Reginaldo S. Romeiro ${ }^{1}$, Roberto Lanna Filho ${ }^{1}$, Dirceu Macagnan ${ }^{2}$, Flávio A.O. Garcia ${ }^{1}$ \& Harllen S.A. Silva ${ }^{3}$ \\ ${ }^{1}$ Departamento de Fitopatologia, Universidade Federal de Viçosa, 36570-000 Viçosa, MG, Brazil; ${ }^{2}$ Centro Federal de \\ Educação Tecnológica de Rio Verde, 75901-970, Rio Verde, GO, Brazil; ${ }^{3}$ Embrapa Mandioca e Fruticultura, 44380-000, \\ Cruz das Almas, BA, Brazil
}

Author for correspondence: Dirceu Macagnan, e-mail: dirceu.macagnan@yahoo.com.br

\begin{abstract}
Isolate UFV-101 of Bacillus cereus was selected in previous studies for promoting growth inducing resistance in plants. In a previous study, supernatant from cultures of the microorganism in a liquid medium was found to induce resistance in tomato foliage against the pathogens Pseudomonas syringae pv. tomato, Xanthomonas vesicatoria, Alternaria solani and Corynespora cassiicola. In the present work the microorganism was grown in a minimal medium for $48 \mathrm{~h}$ and the cells precipitated for centrifugation. The supernatant was concentrated by lyophilization, dialyzed in a $12 \mathrm{kDa}$ cut-off point membrane and fractioned in column containing Sephadex G25 balanced in PBS buffer. The fractions corresponding to a protein peak were applied to tomato seedlings. After four days leaflets were collected and inoculated with the pathogen. C. cassiicola. The numbers of lesions produced by the pathogen on leaflets exposed to the bacterial supernatant were similar to those exposed to acibenzolar-S-methyl but fewer than in those treated with water. It is concluded that the supernatant contained protein which induced resistance in the tomato leaves against C. cassiicola.
\end{abstract}

Keywords: Induced resistance, rhizobacteria, PGPR.

\section{RESUMO}

Evidência da síntese de uma proteína pelo agente de biocontrole Bacillus cereus a qual pode atuar como eliciadora do aumento da resistência em folhas de tomateiro contra Corynespora cassiicola

O isolado UFV-101 foi selecionado em ensaios prévios como promotor de crescimento e indutor de resistência. O sobrenadante, advindo do cultivo desse microrganismo em meio líquido, demonstrou a capacidade de induzir resistência em tomateiro contra os patógenos Pseudomonas syringae pv. tomato, Xanthomonas vesicatoria, Alternaria solani e Corynespora cassiicola. Neste trabalho, a bactéria foi cultivada em meio mínimo por $48 \mathrm{~h}$ e as células precipitadas por centrifugação. O sobrenadante, depois de concentrado por liofilização, foi dializado em membrana com ponto de corte $12 \mathrm{kDa}$ e fracionado em coluna contendo Sephadex G25 equilibrada em tampão PBS. As frações correspondentes ao pico protéico foram aplicadas em mudas de tomateiro. Depois de quatro dias foram coletados folíolos e inoculados com o patógeno desafiador. Folíolos expostos ao sobrenadante da bactéria apresentaram número de lesões semelhantes a aqueles expostos ao acibenzolar-S-methyl e em número inferior a aqueles tratados com água. Desta forma, neste trabalho, a natureza protéica do sobrenadante foi confirmada, bem como, sua atividade indutora de resistência contra o patógeno C. cassiicola.

Palavras-chave: indução de resistência, rizobactéria, PGPR.

\section{INTRODUCTION}

The strain UFV-101 of Bacillus cereus (Silva et al., 2004b) was selected from among 500 isolates of rhizobacteria from healthy tomato plants based on performance as a biocontrol agent. Evidence indicates that the strain is an

Part of the Master Thesis of the second author. Universidade Federal de Viçosa. Viçosa MG. 2008. inducer of systemic resistance (Silva \& Romeiro, 2004; Silva et al., 2004a, b). It is well known that some PGPRs induce systemic resistance to diseases after colonizing plant roots and that this resistance may be expressed locally and at a distance from the site of contact of the biocontrol agent with the host (Loon et al., 1998a, b; Pieterse et al., 2003).

In cases of induced systemic resistance by a PGPR, it is considered that a biochemical signal generated as a consequence of the presence of the rhizobacterium on the root surface is transported throughout the plant and causes what Sticher et al. (1997) referred to as the "induced state" 
in the plant. A molecule, probably of bacterial origin and called the "bacterial determinant" by Loon et al. (1998a), gives rise to the signal, which in turn triggers the induced resistance.

Potential kinds of bacterial determinants include components of the bacterial cell surface layers and molecules synthesized by the rhizobacterium cell and released into the environment (Felix et al., 1999; Meyer et al., 2001; Kunze et al., 2004; Zipfel et al., 2004; Cao et al., 2006; Ortmanna et al., 2006; Wu et al. 2009). Several investigators have focused on the lipopolycaccharides (LPS) as ISR elicitors in plants (Peer \& Schippers, 1992; Romeiro \& Kimura, 1997; Dow et al., 2000; Reitz et al., 2000; Meyer et al., 2001; Mishina \& Zeier, 2007). Their use was first reported by Peer \& Schippers (1991), inducing systemic resistance in carnation against Fusarium oxysporum f. sp. dianthi.

Small molecules released by rhizobacteria that have been implicated in ISR elicitation include salicylic acid (Meyer \& Hofte, 1997; Loon et al., 1998a; Meyer et al., 1998; Chen et al., 1999), siderophores (Thomashow, 1996; Loon et al., 1998a, 1998b; Ramamoorthy et al., 2001), phenazines, and phloroglucinols (Chin-a-Woeng et al., 2001, 2003). However, the ability of macromolecules that are synthesized by rhizobacteria and released into the environment to function as elicitors of ISR in plants has received little attention. Preston et al. (2001) reported Type III Secretory System in isolate SBW25 of the rhizobacterium $P$. fluorescens and, despite recognizing that its function remains unclear, suggested that this system may have an important role in the PGPR biology. As an inducer of ISR in tomato plants, strain UFV-101 of Bacillus cereus was grown by Romeiro et al. (2005) in minimal liquid culture medium. Cells and small molecules were removed from the liquid by centrifugation and extended dialyses, and the supernatant was shown to induce ISR against several fungal and bacterial pathogens. The present paper presents evidence that Bacillus cereus isolate UFV-101 synthesizes macromolecules that act as inducers of resistance and that these molecules have a proteinaceous nature. Isolate UFV-101 was previously tested and selected as a good biocontrol agent against several tomato diseases (Silva et al., 2004a).

\section{MATERIALS AND METHODS}

Experiments were carried out at the Laboratory of Plant Bacteriology and Biological Control, Department of Plant Pathology, The Federal University of Viçosa, Minas Gerais, Brazil. Santa Cruz 'Kada' tomato plants were grown in a non-sterilized mixture of soil, sand and manure $(2: 1: 1$, vol:vol:vol) in a greenhouse at $25^{\circ} \mathrm{C}$ and relative humidity of $70 \%$.

Microorganisms: Bacillus cereus, isolate UFV-101, previously selected as biocontrol agent and inducer of systemic resistance in tomato plants (Silva et al., 2003, 2004a), was grown in the 523 medium of Kado \& Heskett (1970). The isolate was emulsified in 30\% glycerin and preserved at $-80^{\circ} \mathrm{C}$. Corynespora cassiicola, the challenging pathogen, was grown on potato dextrose agar (PDA) medium (Tuite, 1969) and maintained at $4^{\circ} \mathrm{C}$ under mineral oil (Smith \& Onions, 1994). Spores of C. cassiicola for use in inoculations were removed from 7-day old colonies on PDA by means of a brush and collected in distilled water.

Preparation of dialysates: $B$. cereus cells were grown in a modified minimal liquid medium of Simmons (1926) prepared with 5.0 g.L. $\mathrm{L}^{-1}$ of $\mathrm{NaCl}, 2.0$ g.L $\mathrm{L}^{-1}$ of glucose, 2.0 g.L $\mathrm{L}^{-1}$ of $\mathrm{K}_{2} \mathrm{HPO}_{4}, 1.0$ g.L. $\mathrm{L}^{-1}$ of $\mathrm{NH}_{4} \mathrm{H}_{2} \mathrm{PO}_{4}$, and 0.2 g.L. $\mathrm{L}^{-1}$ of $\mathrm{MgSO}_{4} .7 \mathrm{H}_{2} \mathrm{O}$ and adjusted to $\mathrm{pH} 7.0$. At the inflection point of the exponential growth phase, cells were removed from suspension by centrifuging once $(10,000 \mathrm{x}$ g for 15 minutes) in a RC-5B Sorvall refrigerated centrifuge. The supernatant was filtered under sterile conditions through a membrane of $0.45 \mu \mathrm{m}$ pore size, transferred into dialysis bags (cut off point $12 \mathrm{kDa}$ ) and dialyzed with continuous stirring against 400 volumes of distilled water at $4^{\circ} \mathrm{C}$. The water was changed several times during the $48 \mathrm{~h}$ of dialysis. Dialysates were lyophilized and stored at $-20^{\circ} \mathrm{C}$ for later use.

Partial resolution of crude dialysates by gel filtration: A glass column $60 \mathrm{~cm}$ long and $2 \mathrm{~cm}$ in diameter was filled with coarse grade Sephadex G25 and equilibrated with phosphate-buffered saline (PBS) (1.44 g.L. $\mathrm{L}^{-1}$ of $\mathrm{Na}_{2} \mathrm{HPO}_{4}$; 0.24 g. $\mathrm{L}^{-1}$ of $\mathrm{KH}_{2} \mathrm{PO}_{4} ; 0.2$ g. $\mathrm{L}^{-1}$ of $\mathrm{KCl} ; 8.0$ g. $\mathrm{L}^{-1}$ of $\mathrm{NaCl}$; adjusted to $\mathrm{pH}$ 7.0). The flow rate was set at 48 drops. $\mathrm{min}^{-1}$, (equivalent to $3 \mathrm{~mL} \cdot \mathrm{min}^{-1}$ ). The lyophilized crude dialysates were dissolved in $15 \mathrm{~mL}$ of PBS. Successive 3 $\mathrm{mL}$ aliquots were applied onto the column, from which 3 $\mathrm{mL}$ fractions were collected by means of a Mini Scargot Fractionator (Gilson). Protein in the crude dialysates was quantified according to Bradford (1976) and the results were expressed as BSA equivalents. The anthrone method of Gerhardt (1994) was used to estimate total hexoses and the results were expressed as glucose equivalents.

Exposure of tomato plants to protein extract and challenging pathogen inoculation: Santa Cruz 'Kada' tomato plants for use in the experiment were grown in soil in plastic pots in a greenhouse. Leaves of forty-day-old plants were sprayed with the protein extract, acibenzolarS-methyl (ASM) (0,05 g.L $\mathrm{L}^{-1}$ water) (positive control) or water (negative control). Four days later, two leaflets were detached from the mid canopy of each plant, placed in moist chambers (plastic tray of $40 \times 20 \mathrm{~cm}$ ) at $25^{\circ} \mathrm{C}$ and immediately sprayed with a conidial suspension of $C$. cassiicola $\left(3.0 \times 10^{4}\right.$ spores. $\mathrm{mL}^{-1}$ water). The use of detached leaves allowed a large number of plants to be examined under controlled conditions. When symptoms were well developed, lesions were counted and the mean number of 
lesions per leaflet was calculated. There were two leaflets of each of ten plants per treatment and one plant per pot was considered as a replicate. Statistical analysis was performed according to Tukey's test.

\section{RESULTS}

Growth of isolate UFV-101 in the modified Simmons minimal liquid medium was much slower than in rich media such as medium 523 of Kado and Heskett (1970). Gijsegem et al. $(1995,2000)$ pointed out that detection of macromolecules released by bacteria into the supernatant is easier when the cells are grown in a minimal culture media. The white powder obtained after the supernatants were filtered, dialyzed and lyophilized dissolved readily in water, PBS, or saline. The elution profile obtained after the solution was passed through the G25 Sephadex column revealed a large protein peak encompassing fractions 10 to 22 , and also a small fraction of hexose, which could be a part of glycoprotein (Figure 1).

Figure 2 shows that, relative to the water control, the severity of the target spot (C. cassiicola) significantly decreased when the collective protein fraction (10 to 22) and the positive control ASM (Acibenzolar-S-Methyl) were applied to the tomato foliage four days before the leaves were challenge-inoculated with $C$. cassiicola. This finding indicated that the protein fraction from isolate UFV-101 protected the tomato leaves against the pathogen.

\section{DISCUSSION}

Working with the same model system, Romeiro et al. (2005) had shown that crude dialysates obtained from supernatants of liquid minimal culture medium in which
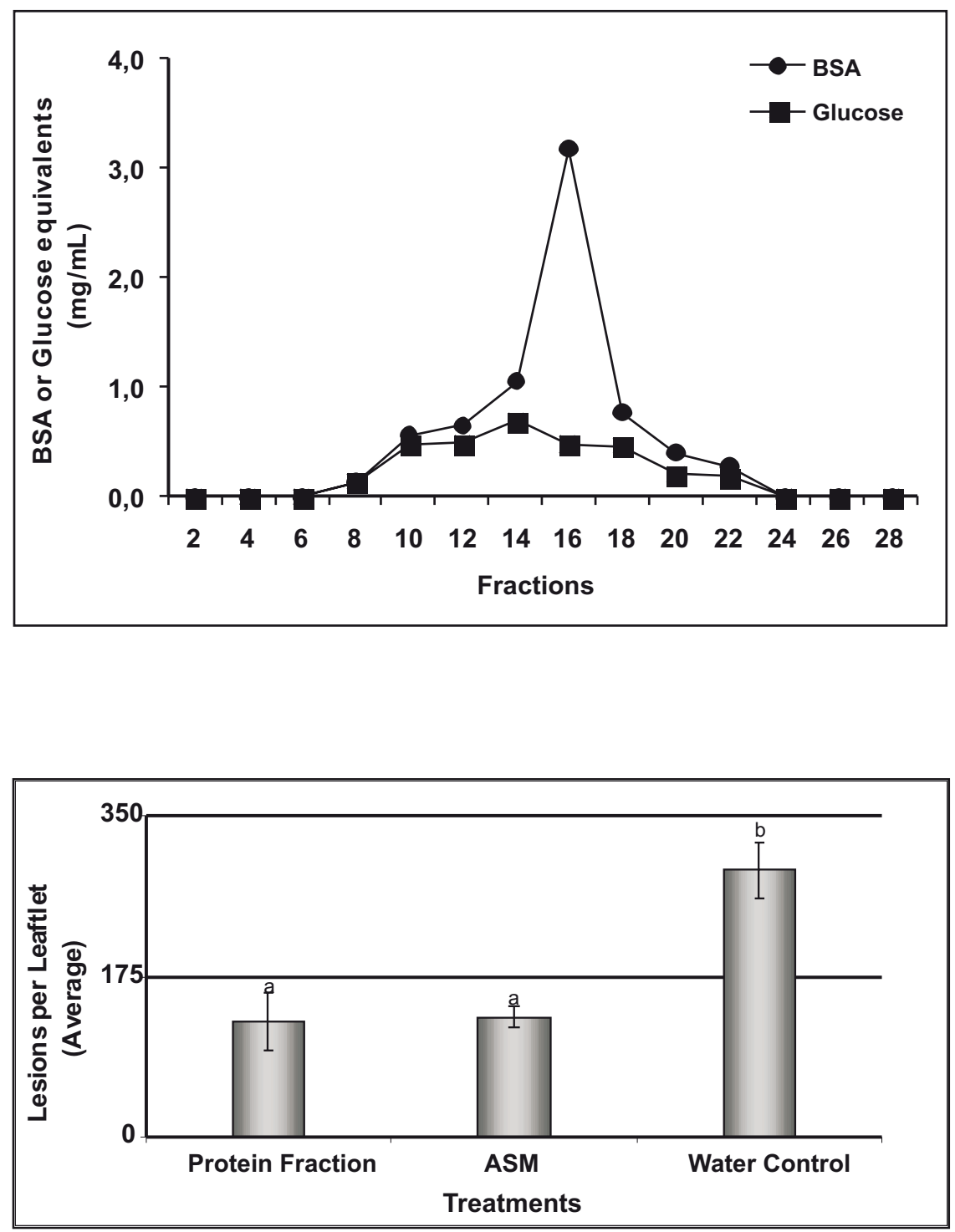

FIGURE 1 - Elution profile of a supernatant dialysate $($ cut off $=12 \mathrm{kDa})$ obtained from a liquid culture of Bacillus cereus UFV-101 grown in a minimal medium. The protein peak encompassed fractions $10-22$, after resolution by gel filtration in a chromatography column containing Sephadex G25 equilibrated in PBS buffer.
FIGURE 2 - Numbers of lesions produced by $C$. cassiicola in tomato leaflets exposed to proteinaceous fractions 10 to 22 of the supernatant dialysate of Bacillus cereus, acibenzolarS-methyl or water. Average values followed by same letter do not differ significantly (Tukey test: $\mathrm{P}=0.05$ ). The columns represent the average values and the bars represent the standard errors of the averages. 
UFV-101 was growing were able to induce resistance in tomato against multiple pathogens. In the present investigations, a clear protein peak emerged when such a dialysate was resolved by gel filtration in a SephadexG25 column and the eluted aliquots were analyzed. The pooled eluates from the protein peak were shown to be associated with an observed increase in resistance of the tomato leaves against the challenge pathogen C. cassiicola. Additionally, Romeiro et al. (2005) found no direct activity of the dialysate "in vitro" against the pathogens Alternaria solani, Corynespora cassiicola, Pseudomonas syringae pv. tomato, Pseudomonas corrugata, Pseudomonas syringae pv. syringae, Xanthomonas vesicatoria, Clavibacter michiganensis subsp. michiganensis and Ralstonia solanacearum.

Silva et al. (2004b) observed increased activity of enzymes lipoxygenase (LOX), phenylalanine ammonialyase (PAL) and peroxidase (POX) in a tomato-rhizobacteria interaction against the pathogen $P$. syringae pv. tomato, which was interpreted to mean that the rhizobacteria induced ISR in the tomato plants. Subsequently, given the results obtained by Romeiro et al. (2005), who demonstrated that the dialysate protected tomato plants against different plant pathogens without any phytotoxic effect, and those presented in the present paper, we interpret the response of the tomato plants to UFV-101 to be induced systemic resistance and that this ISR did not require physical contact of the bacteria with the tomato plant. Our observations clearly indicate that UFV-101 synthesizes and releases proteins with activity as elicitors of induced resistance in tomato plants, which may give a broad spectrum of action against multiple pathogens in tomato (Silva et al., 2004a, 2004b; Romeiro et al., 2005). However, we cannot confirm the existence of ISR or systemic acquired resistance (SAR). Thus, future studies are being conducted to investigate the occurrence of both types of resistance.

The aforementioned results provide sound evidence that the PGPR under investigation synthesizes proteins which are released into the environment and act as elicitors of induced resistance in tomato. Given that only molecules larger than $12 \mathrm{kDa}$ were in the dialysate and that the activity of induced resistance coincided with the protein peak in the elution profile, our data support the conclusion that one or more proteins synthesized and released by $B$. cereus into the cell environment elicited the observed increase in resistance in the tomato leaflets against $C$. cassiicola. Research groups in the Laboratories of Plant Bacteriology of the Federal Universities of Viçosa (UFV) and Lavras (UFLA) have concentrated their studies towards the understanding of rhizobacteria-plant interactions, especially those related to the induction of disease resistance in plants. The present paper contributes to a better understanding of how PGPR induces resistance in plants and may eventually lead to the development of bioproducts such as Messenger ${ }^{\circledR}$ and ProAct ${ }^{\circledR}$.

\section{ACKNOWLEDGMENTS}

The authors thank Conselho Nacional de Desenvolvimento Científico e Tecnológico - CNPq for partially financing the work and for granting scholarships.

\section{REFERENCES}

Bradford MM (1976) A rapid and sensitive method for the quantitation of microgram quantities of protein utilizing the principle of protein-dye binding. Analytical Biochemistry 72:248254.

Cao J, Bates SL, Zhao JZ, Shelton AM, Earle ED (2006) Bacillus thuringiensis protein production, signal transduction, and insect control in chemically inducible PR-1a/cry1 Ab broccoli plants. Plant Cell Reports 25:554-560.

Chen C, Belanger RR, Benhamou N, Paulitz TC (1999) Role of salicylic acid in systemic resistance induced by Pseudomonas spp. against Pythium aphanidermatum in cucumber roots. European Journal of Plant Pathology 105:477-486.

Chin-A-Woeng TFC, Bloemberg GV, Lugtenberg BJJ (2003) Phenazines and their role in biocontrol by Pseudomonas bacteria. New Phytologist 157:503-523.

Chin-A-Woeng TFC, Broek DVD, Voer GD, Drift KMGMVD, Tuinman S, Thomas-Oates JE, Lugtenberg BJJ, Bloemberg GV (2001) Phenazine-1-carboxamide production in the biocontrol strain Pseudomonas chlororaphis PCL1391 is regulated by multiple factors secreted into the growth medium. Molecular Plant-Microbe Interactions 14:969-979.

Dow M, Newman MA, Roepenack EV (2000) The induction and modulation of plantdefenseresponses by bacteriallipopolysaccharides. Annual Review of Phytopathology 38:241-261.

Felix G, Duran, JD, Volko S, Boller, T (1999) Plants have a sensitive perception system for the most conserved domain of bacterial flagellin. Plant Journal 18:265-276.

Gerhardt PE (1994) Methods for General and Molecular Bacteriology. Washington. American Society for Microbiology.

Gijsegem F, Genin S, Boucher C (1995) Hrp and avr genes, key determinants controlling the interaction between plants and gram-negative phytopathogenic bacteria. In: Singh US, Singh RP, Kohmoto K(Eds) Pathogenesis and host specificity in plant diseases. Kidlington UK. Elsevier Science. pp. 346-435

Gijsegem F, Vasse J, Camus JC, Marenda M, Boucher C, Gijsegem F (2000) Ralstonia solanacearum produces Hrp-dependent pili that are required for PopA secretion but not for attachment of bacteria to plant cells. Molecular Microbiology 36:249-260.

Kado CI, Heskett MG (1970) Selective media for isolation of Agrobacterium, Corynebacterium, Erwinia, Pseudomonas and Xanthomonas. Phytopathology 60:969-979.

Kunze GU, Zipfel C, Robatzek S, Niehaus K, Boller T, Felix G (2004) The $\mathrm{N}$ terminus of bacterial elongation Factor Tu elicits innate immunity in Arabidopsis plants. Plant Cell 16:3496-3507.

Loon LCV, Bakker PAHM, Pieterse CMJ (1998a) Systemic resistance induced by rhizosphere bacteria. Annual Review of Phytopathology 36:453-483. 
Loon LCV, Bakker PAHM, Pieterse CMJ, Duffy B, Rosenberger U, Defago G (1998b) Induction and expression of PGPR-mediated induced resistance against pathogens. Bulletin OILB SROP 21:103-110.

Meyer A, Puhler A, Niehaus, K (2001) The lipopolysaccharides of the phytopathogen Xanthomonas campestris pv. campestris induce an oxidative burst reaction in cell cultures of Nicotiana tabacum. Planta 231:214-222.

Meyer GD, Hofte M (1997) Salicylic acid produced by the rhizobacterium Pseudomonas aeruginosa 7NSK2 induces resistance to leaf infection by Botrytis cinerea on bean. Phytopathology 87:588-593.

Meyer GD, Hofte M, Duffy B, Rosenberger U, Defago G (1998) Induction of systemic resistance by the rhizobacterium Pseudomonas aeruginosa 7NSK2 is a salicylic acid dependent phenomenon in tobacco. Bulletin OILB SROP 21:117-121.

Mishina TE, Zeier J (2007) Pathogen-associated molecular pattern recognition rather than development of tissue necrosis contributes to bacterial induction of systemic acquired resistance in Arabidopsis. Plant Journal 50:500-513.

Ortmanna I, Conrathb U, Moerschbachera BM (2006) Exopolysaccharides of Pantoea agglomerans have different priming and eliciting activities in suspension-cultured cells of monocots and dicots. FEBS Letters 580:4491-4494.

Peer R, Schippers B (1992) Lipopolysaccharides of plant-growth promoting Pseudomonas sp. strain WCS417r induce resistance in carnation to Fusarium wilt 98:129-139

Pieterse CMJ, Pelt JAV, Verhagen BWM, Ton J, Wees SCMV, Leon-Kloosterziel KM, Loon LCV (2003) Induced systemic resistance by plant growth-promoting rhizobacteria. Symbiosis Rehovot 35:39-54.

Preston GM, Bertrand N, Rainey PB (2001) Type III secretion in plant growth-promoting Pseudomonas fluorescens SBW25. Molecular Microbiology 41:999-1014.

Ramamoorthy V, Viswanathan R, Raguchander T, Prakasam V, Samiyappan R (2001) Induction of systemic resistance by plant growth promoting rhizobacteria in crop plants against pests and diseases. Crop Protection 20:1-11.

Reitz M, Rudolph K, Schroder I, Hoffmann-Hergarten S, Hallmann J, Sikora RA (2000) Lipopolysaccharides of Rhizobium etli strain $\mathrm{G} 12$ act in potato roots as an inducing agent of systemic resistance to infection by the cyst nematode Globodera pallida. Applied and Environmental Microbiology 66:3515-3518.
Romeiro RS, Kimura O (1997) Induced resistance in pepper leaves infiltrated with purified elicitors from Xanthomonas campestris pv. vesicatoria. Journal of Phytopathology 145:495-498.

Romeiro RS, Lanna Filho R, Vieira Junior JR, Silva HSA, BaracatPereira MC, Carvalho MG (2005) Macromolecules released by a plant growth-promoting rhizobacterium as elicitors of systemic resistance in tomato to bacterial and fungal pathogens. Journal of Phytopathology 153:120-123.

Silva HSA, Romeiro RS, Mounteer A (2003) Development of a root colonization bioassay for rapid screening of rhizobacteria for potential biocontrol agents. Journal of Phytopathology 151:4246.

Silva HSA, Romeiro RS (2004) Isolamento e seleção massal de rizobactérias indutoras de resistência sistêmica à manchabacteriana-pequena do tomateiro. Revista Ceres 51:345-354

Silva HSA, Romeiro RS, Carrer-Filho R, Pereira JLA, Mizubuti ESG, Mounteer A (2004a) Induction of systemic resistance by Bacillus cereus against tomato foliar diseases under field conditions. Journal of Phytopathology 152:371-375.

Silva HSA, Romeiro RS, Macagnan D, Halfeld-Vieira BA, Baracat-Pereira MC, Mounteer A (2004b) Rhizobacterial induction of systemic resistance in tomato plants: non-specific protection and increase in enzyme activities. Biological Control 29:288-295.

Simmons JS (1926) A culture medium for differentiating organisms of typhoid-colon aerogenes groups and for isolation of certain fungi. Journal Infective Disease 39:209-214.

Smith D, Onions AHS (1994) The preservation and maintenance of living fungi. Surrey. International Mycological Institute.

Sticher L, Mani BM, Metraux JP (1997) Systemic acquired resistance. Annual Review of Phytopathology 35:235-270.

Thomashow LS (1996) Biological control of plant root pathogens. Current Opinion in Biotechnology.

Tuite J (1969) Plant Pathological Methods. Minneapolis. Burgess Publishing Company.

Wu HJ, Wang SA, Qiao JQ, Liu J, Zhan J, Gao XW (2009) Expression of $\mathrm{HpaG}(\mathrm{Xooc})$ Protein in Bacillus subtilis and its Biological Functions. Journal of Microbiology and Biotechnology 19:194-203.

Zipfel C, Robatzek S, Navarrol L, Oakeley EJ, Jones JD, Felix G, Boller T (2004) Bacterial disease resistance in Arabidopsis through flagellin perception. Nature 428:764-767. 